\title{
Old communities, excluded women and change in Western Thrace (Thracian Greece, the Provinces of Xanthi, Rhodopi and Evros $)^{1}$
}

\section{Natalia Ribas Mateos}

Universitat Autònoma de Barcelona. Departament de Sociologia

08193 Bellaterra (Barcelona). Spain

mazo@arquired.es

\begin{abstract}
This article is based on research conducted in Thrace, a Greek region bordering Turkey and Bulgaria. It highlights the complexity of the case of Thrace within the context of the Southern European immigration model. After presenting an overview of the region, the article goes on to analyse the historical context, the importance of international relations and the demographic interests that are present when adopting immigration policies. An integrated approach to policies is considered - those policies for minorities and those for the Pontian Greek immigrants - which represents the paradoxical strategies of Greek treatment of «difference».
\end{abstract}

Key words: Thrace, Ottoman empire, Pontios, Pomaks, Turks, Muslim, demography, EIYAPOE programme, women.

\section{Resumen. Antiguas comunidades, mujeres excluidas y cambio en Tracia Occidental}

Este artículo está basado en una pequeña investigación realizada en Tracia, una región griega fronteriza con Turquía y Bulgaria. El texto pone de relieve la complejidad del caso de dicha región en el contexto de un modelo de análisis de la inmigración para la Europa del sur. Una vez introducido el porqué de la selección de Tracia, el artículo revisa el contexto histórico, la importancia de las relaciones internacionales y los intereses demográficos en la adopción de unas determinadas políticas de inmigración. El artículo utiliza un enfoque integrado en el que dos tipos de políticas son tomadas en consideración conjuntamente: las políticas sociales que conciernen a las minorías y aquéllas destinadas a los inmigrantes pontios, ejemplificando así las paradójicas estrategias de la concepción oficial griega de la "diferencia».

Palabras clave: Tracia, Imperio otomano, pontios, pomacos, turcos, musulmanes, demografía, programa EIYAPOE, mujeres.

1. I would like to thank the following people for their collaboration in the course of my research in Thrace: the staff of the Kappi (day-care centre for the elderly) in Komitini (especially to Tula Tsatsikou and Caterina), the social workers of the EIYAPOE programme (especially Xristos Pashalakis and Maria Fotiadu), the Democritus University of Thrace (especially Maria Petmesidou and Theano Kallinikaki), the municipality of Sappes (especially Makis Kenaridis and Dukas Dimostenis), Petros Anastasiadis, Ahmet Emin, Hülya Emin, Cristini Gianuli and Louise Saltsidou-Mateossian. In Barcelona I would also like to thank John Etherington from the UAB for the repeated revisions of the paper. This report was financied with a research grant of the DG XII, European Commission-TMR Programme, under the Greek supervision of Laura Alipranti, EKKE, Athens. 


\section{Summary}

$\begin{aligned} & \text { 1. Introduction } \text { 5. Family context and excluded women } \\ & \text { 2. Why the case of Thrace? } \text { 6. Different perceptions of social right } \\ & \text { in Western Thrace } \\ & \text { 3. Foreign immigration in Greece: the } \begin{aligned} \text { 7. Conclusions } \\ \text { looking glass of the international scene }\end{aligned} \\ & \begin{aligned} & \text { 4. Old communities (Turks, Pomaks, } \text { References } \\ & \text { Roma and Pontios) }\end{aligned}\end{aligned}$

This report outlines the results of research conducted in January and February of 1999 in Thrace ${ }^{2}$, a Greek region, within the wider context of the situation of immigrant families in Greece and in Southern Europe. The aim of this research is to examine how different immigration policies have affected immigrants, focusing in particular on families from non-EU countries ${ }^{3}$. The fieldwork is mainly based on 13 in depth-interviews with key representatives of different groups, especially those related to local authorities and associations, and were conducted in Komotini, Alexandropouli, Sappes and Tihero (with the latter two being villages, one in the Rodhopi province and the other in the Evros province). Sappes, where three different communities live ${ }^{4}$, can be considered to be a paradigmatic case.

I focus here only on the region of Thrace. The article has three main parts each divided into seven different sections. First it describes the main issues concerning the case study of Thrace. It then analyses the different perceptions

2. The areas referred to today by the Turks as Western Thrace and by the Greeks as Thrace came under Ottoman control in 1263-1364 after the defeat of a combined Serb, Bosnian, and Hungarian army in 1366 on the Maritsa river near the city of Edirne (HRW, 1998: 7).

3. Through two presidential decress (358/98 and 359/97) the Greek government has cleared the way for the legalisation of immigrants. Through two successive phases of legalisation, foreigners are elegible to obtain the so-called "white card" and then, the "green card", permit to stay and permit to work in Greece. For more information on the Greek legislation of immigrants, see the work by Fakiolas and Maratou-Alipranti in this monograph.

4. Sappes was also selected because it differs in many ways to other villages. In this municipality, controlled by the PASOK (the Greek Socialist Party), the actors involved appear to be searching for a different model of integration in contrast with other municipalities. These efforts have benefited from the "Capodistria Plan", which tends to concentrate municipalities into bigger geographical areas. Being aware of the strategical location of the area, close attention is paid to both Turkish-Greek relations within other municipalities and with Bulgarian-Greek relations, and also learning Turkish as means of getting closer to local voters and to take advantage of any future economic development in Greek-Turksih relations is taken as a important future strategy. There is also a concern about the formation of spatial segregation by the concentration in areas of different communities, especially the "residential parts» where the Pontios live which are quite far away from the centre of the town. In the following interview we can clearly see the situation of «mixed communities»:

In this particular area is the only area in Greece that we have $40 \%$ local Christians who speak Greek language, 30\% local Moslems who speak Turkish, and 25\% who came from Russia, who are Pontios and who speak language (mayor of Sappes). 
of diverse social actors towards social policies related to the division of communities. Finally, it puts forward very briefly in the conclusions an unusually integrated approach for viewing the interaction of new immigration and old communities in the new reality of Thrace.

«Old communities» here refer to the different communities that have been living in Thrace for many years, and the newly-arrived immigrants called Pontios (Pontian Greeks) from the former Soviet Republics who are also old Greek communities. «Excluded women» refers to the lack of women's presence in associations as well as to the lack of specific programmes which approach gender issues. The last element, "change», applies to the transformations that have taken place in the second half of the nineties: ${ }^{5}$ on the one hand, socio-economic changes affecting the whole area and, on the other, a decentralisation process, still very weak, which has just started within the Greek administration.

This article is informed by the critical spirit of the social sciences. No political confrontation is intended nor does it seek to provide practical information to policy-makers and administrators.

\section{Introduction}

Two different themes are taken into consideration here: «new immigration», «new minorities» and «old minorities». As regards to new immigration, various authors (see Fakiolas and Maratou-Alipranti in this monograph) have offered a close account of the complexities of immigration policies in the case of Greece by showing what is arguably the most «awkward» member state of the EU. Possibly the main reason for the uniqueness of the Greek case is the fact that the Balkan scenario plays an important role in immigration issues. An important aspect of the Thracian region is that it has been the main point of arrival and settlement for Pontios (ethnic Greeks from the former Soviet republics) in Greece.

In terms of the «old minorities», the aim is to show how the intricate problem of mixed communities and the impossibility of drawing "ethnic boundaries» in the Eastern Mediterranean area is one of immediate relevance. The Balkans has always been an area where not only dramatic historic events have taken place and cultures crossed, but also where peoples of different nations have exercised influence over each other. The Muslim community (Turks, Pomaks, Roma) in Western Thrace illustrates very clearly the problems of trying to differentiate between groups for whom Turkey represents a kin-state with which ties of ethnicity and religion can be traced (Poulton, 1997a). Religion and not ethnicity - a common problematic distinction in the Balkan region- has so

5. «We have always been quite a backward region, but over the last few years we have received a great deal of investment, thanks to both Europe and to our government. Until just a few years ago this was just an isolated area next to Turkey, and as you know, without any economic relations with the neighbouring country. The border with Bulgaria was only opened in 89» (mayor of Tíhero). 
far been the criterion used by the Greek government to distinguish Greeks from Turks, even if minorities (Turkish, Pomaks, Roma) have chosen to define themselves as Turkish. Ethnic Turks have lived in the region since at least the XIV century and they are Greek citizens, protected by the Treaty of Laussane (as regards religion, language, culture and equality before the law), and, as Greek citizens, they also enjoy the protection of Greek law and the European Convention of Human Rights.

Taking these two different settings - the construction of the different communities - , here I would like to highlight the problems of diversity from the two sides of the same coin, be they old minorities or the new ones.

My central aim in this paper is to unmask a scarcely-known reality that is characterised by a lack of literature on the issue, whether in Greek or in English. Indeed, the Greek scientific community has often ignored Thrace. I have tried to give a sociological reading (with political issues almost always present), when most of the reduced material found - be it in Greek, French or Englishdeals basically with two perspectives: either folkloric visions of the region or with reports written by human rights activists. To do so, I will use two main perspectives: the historical perspective and the socio-economic one in order to analyse the problems faced by the communities.

From the historical perspective, I shall argue that current immigration policies are in part a continuation of the demographic policies carried out by the Ottoman Empire. Furthermore, it is common knowledge that Pontios communities were made to settle in this specific area in order to balance the presence of the Turkish/Muslim community, given the government concern about the growing birth-rate of the latter.

In terms of the historical background we should point out that if we refer today to the different communities we should firstly refer to the prevailing organisation of confessional communities during the Ottoman Empire. In this sense, Greeks who lived in the space of today's Turkey, Pontios (originally from certain areas of the Black Sea) from the ex-Soviet Union, Pomaks, the Turkish population and gypsies all follow the legacy of the Ottoman system in terms of the division of communities, although, inserted today in the context of the development of the young Greek nation-state. As a more recent historical background, we should point out the decomposition of the Socialist bloc, the interferences of Greek and Turkish nationalism and the Balkan factor, where the combination of religion and ethnicity can be considered a regional specificity. Therefore, Greek immigration looks, in a way, back to history; it looks to the ruins of the Ottoman Empire and of Soviet socialism.

After the 1990 disturbances in Komotini, driven by inter-communal conflicts in Western Thrace, there was a change in governmental policies focused on greater economic development for the region and the settlement of Pontian Greeks arriving from the Soviet Union, the elimination of some of the more petty examples of long-standing discrimination, and the encouragement of division among the Muslim community (Turks, Pomaks, and Muslim Roma) (Poulton, 1997b: 87). 
Immigration policies cannot be detached from the socio-economic situation of the different communities already living there. Furthermore, the concept of the Greek diaspora becomes essential not only for understanding the idea of Greek national construction but also for understanding better the outline of immigration policies especially aimed at the Pontios. The notion of diaspora is very important in order to give a sense of a common identity. As seen throughout the interviews, the idea of diaspora is mixed in with the issue of immigration and with the construction of national identity. This Greek word which means dispersion has been generally used to recall the forced Jewish dispersion during ancient times. The notion of diaspora is linked to a strong identity consciousness which a minority group uses as a reference even when the minority is settled in different territories. This identity consciousness uses the existence of an organisation structured along political, religious or cultural lines. The Pontios affirmation of identity is more clearly witnessed from the seventies onwards in the shape of cultural and religious identity, where identity is mainly inherited through an extended family system. The memory of this diaspora is based on the loss of an original territory, which for the Pontios is often dramatically evoked due to the memories of the genocide suffered at the hands of the Turks. The new territory is then found in Greece, introducing Neos or Nea on the place names, such as the case of Nea Sanda in Rhodopi, the New Sanda.

Therefore, historical conditions play a key role in the construction of collective identity in Thrace, both in the perception of their own community as well as in the perception of "other» communities. This feeling came out strongly in each of the interviews: "We have historical wounds, it will take a few generations more if we want to forget those historical illusions, whether Christians or Muslims we all come from those historical fractures».

When delineating ideal-types of accommodating immigrant minorities in liberal democracies, two poles are often distinguished: 1) those which actively recognise and support different cultural groups by means of public policies without contracting individual basic rights and 2) those which are based on individual rights and state neutrality with respect to cultural membership. In our case, we can distinguish two sides of the same coin: an assimilationist policy through the promotion of the settlement of Pontios and a communitarian policy for the different communities living in the region, based on the Treaty of Laussane (and on the state of Greek-Turkish relations). Nevertheless, ideal categories are too difficult to be used as analytical tools when we face such a complex case. We can see here how the Thracian case directly addresses the very issue of the "Greek paradox", which recognises difference in a complex way (through a historical treatment) and promotes assimilation through a badly planned policy (for Pontios).

\section{Why the case of Thrace?}

While reading in 1996 the part on Thrace in «Islams of Europe» by Gerassimos Notaras, I became interested in trying to understand further the complex social 
reality represented by the multi-community model of Thrace. Afterwards, through further reading I became aware of how Thrace represents an exceptional example of the Greek setting.

The region of Thrace administratively comes under the «periferia Anatolia (Eastern) Makedonia-Thraki» (having Komotini as its capital), with the following provinces: Kavala, Xanthi, Rhodopi, Evros (see map 1, p. 126-127). In 1923, the Treaty of Lausanne confirmed and recognised the Treaties of Neigi and Serves. Western Thrace became part of Greece, but Eastern Thrace was given to the Turks. Thus, the region was divided into two parts. Originally the unification of Thrace with Greece had come about with the Treaty of Neigi in 1919.

This historical context is important in order to understand the organisation of the different communities today. First of all we should go back in history, to the time when Smirni was burnt down, Asia Minor was destroyed, and the region of Thrace began to take in refugees and offer them hospitality as they fled Ataturk's forces. These events have had a strong historical impact, and became commonly known as the "Asia Minor catastrophe». This issue is very much related to the so-called «Megali Idea», the inherited idea of Greece from ancient times, which would include those territories in Asia Minor with ancient Greek settlements in what it is today a part of Turkey. Greek nationalism (which had his golden period at the beginning of the XX century) was founded on the "Megali Idea»; the dream that placed Greece in two continents -Europe and Asia - and five seas - Egean, Ionian, Black Sea, Marmara, and Crete Sea-, having Constantinople (today's Istambul) as its capital. It was president Venizelos that called on the Greeks to fight for the «Magna Greece», after occupying Western Anatolia, their mission was to free their «repressed brothers». The second historical chain of events are those surrounding the more recent invasion by Turkey of Cyprus in 1973.

The main reasons that have made the region of Thrace an interesting case of analysis are, in the first place, its special geostrategic position, secondly, its complexity because it embodies the Balkan element of Greece, and thirdly, because the case of Thrace highlights several important contrasts within the context of Greece.

Firstly, this region occupies a key place on the map given its location at the cross-roads of many countries. The Bulgarian and Turkish borders are present in the region of Thrace, borders mostly closed by natural barriers (such as the mountains in the Epiros region bordering Albania) and the Evros river in the province of Evros. Despite the strong military presence in Thrace (on both the Western side by Greek soldiers, and on the East by Turkish soldiers) many asylum seekers enter Greece illegally from Turkey and avoid the border by crossing the Evros river, or, as an increasingly used alternative, many are now choosing to disembark clandestinely on one of the many Greek islands close to the Turkish coast. Since no re-admission agreement exists between Greece and Turkey, it is impossible for these people to be returned to Turkey.

In this light, the Greek-Turkish border on the Thracian side is really tightly sealed, and in this sense is very different from the Spanish-Moroccan 
borders of Sebta and Melilla where flows of immigrants are heavy (even if the «new wall» between North and South has been built). That the border crossing is marked by a heavy military presence can be detected many kilometres away from the actual border. Border crossing is difficult, for example, one of the border crossings, that of Castanidis, only opens until 11 in the morning.

Secondly, we should emphasise the diversity of communities living in the region. By taking into account, the "Balkanic» side of Greece this diversity emerges strongly, which to some extent makes Greece more representative when viewed as a national case in the overall context of Southern Europe.

Thirdly, the selection of this region also helps in illustrating the contrast between a high immigration pole (Athens, Attiki region), and a low immigration pole (Thrace), between a big metropolitan area and a more depopulated and rural one, and between regions with very different levels of development of social services. Thus, there emerges a clear division between Athens and the Salonica area on the one hand, and, Thrace and some of the more isolated areas on the other. The same could be said of the European programmes: the least favoured areas do not have access to the kind of qualified staff so necessary for social programmes, which in turn reflects the general lack of trained personnel in the Thracian occupational structure ${ }^{6}$.

Generally speaking migrants are considered to be those who have come to the country of destination for reasons of work, although, as we shall see, there are complex differences between immigration processes which are relevant for the present study. Thrace was not chosen merely because of the «new migrations» of the 1990s (completely different from the Attiki regions where the capital is situated) but it was also chosen due to the fact that it represents a strong mosaic of Balkan cultures.

Since the changes in Eastern Europe at the beginning of the 1990's, the social sciences have shown increasing interest in minority issues and in the revival of nationalism. As a region in which such issues are very important both historically and politically, attention in the Balkans is constantly focused on all of the factors that go to make up the whole geopolitical complexity. In the case of Greece we should begin by pointing out that the Greek government recognises only one minority, the "Muslim» minority, living in Thrace and protected under the 1923 Treaty of Lausanne. However, most «Muslims» identify themselves as Turks, regardless of their ethnic origin (Turkish, Roma or Pomak origin).

6. Curiously enough the same phenomenon occurs with administrators for European programmes in the border area between Portugal with Spain, where there is a flow of transnational qualified workers migrating from a saturated Spanish labour market. 


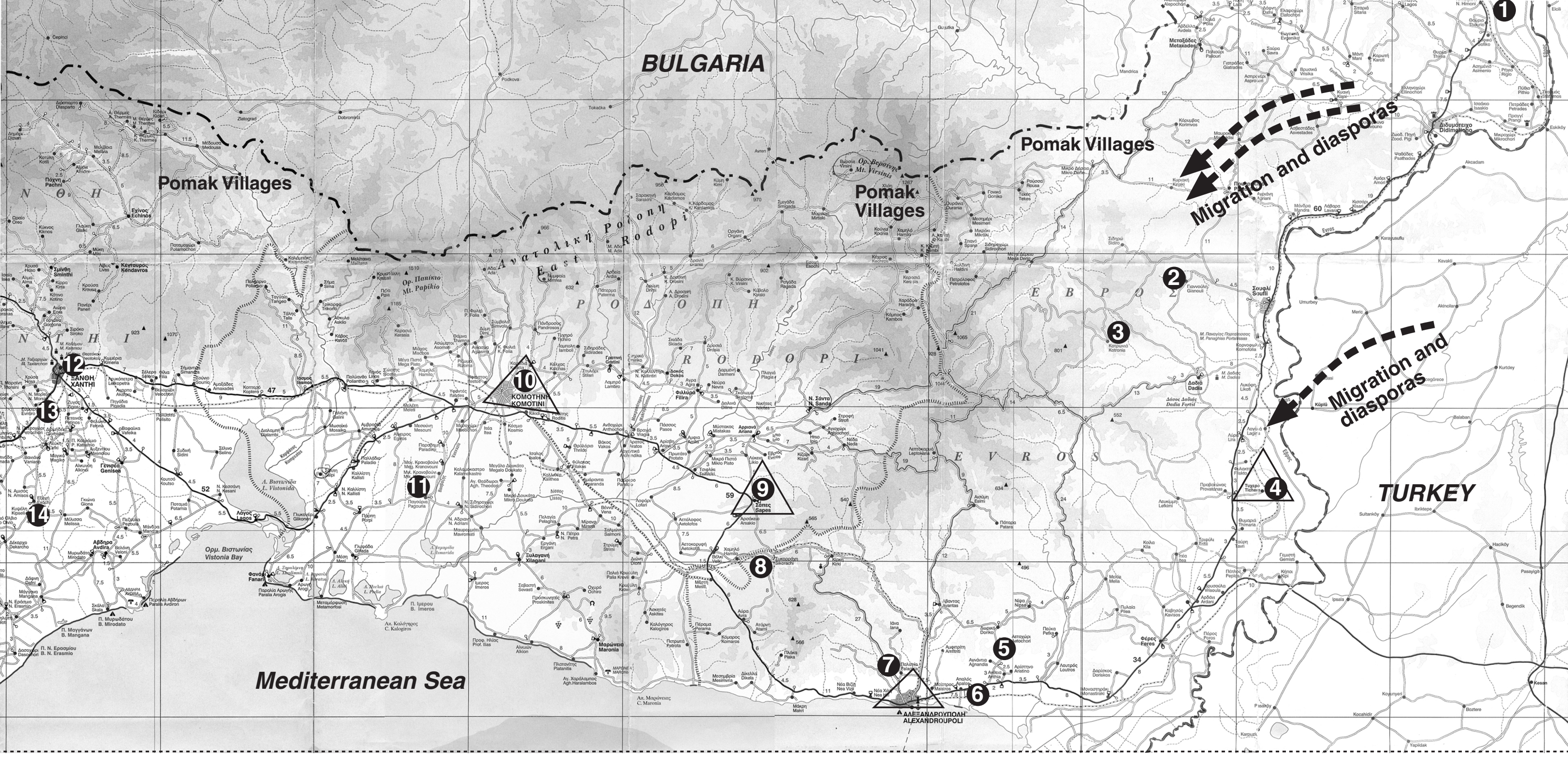

\section{Map of Western Thrace: Location of Pontios' settlements}

This is a segment of the map corresponding to the administrative region of Eastern Makedonia-Thraki. This administrative region includes the Periferia Anatolia (Eastern)-Makedonia-Thraki (provinces of Kavala, Xanthi, Rhodopi and Evros). However, the area shown here only covers part of the province of Xanthi, and the provinces of Rhodopi and Evros.

The field-work (January-February 1999) covered the following places: Komotini, Alexandroupouli, Sappes, and Tíhero.

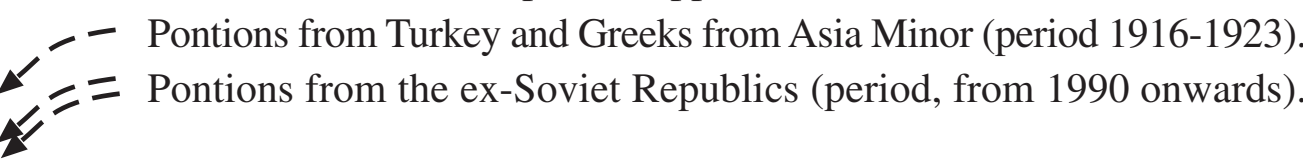

Source for the original map: Road Editions 41 (Ilia Iliou Str. 11743 Athens). Scale 1:250000
EYAPOE programme (period 1991-1995). Main centres for Pontios settlements (see from East to West of the region). Number of built houses*:

1. Orestiada (not covered in the map) 70 houses

2. Gianuli (61 houses)

3. Kotronia (5 houses)

4. Tichero ( 35 houses)

5. Aetochori (11 houses)

6. Apalos (30 houses)

7. Palaghia ( 240 houses)

8. Sikorachi ( 20 houses)

9. Sappes (281 houses)

10. Komotini (Ektenepol) 800 houses

11. Pagouria ( 80 houses)

12. Xanthi (500 houses)

13. Evmiro (153 houses)

14. Exochi (18houses)
Other locations of the administrative region not covered in the map are:

-Avato Xanthis (79 houses)

-Exohi Xanthis (18 houses)

-Zigos Kavalas (162 houses)

* Various sources (interviews) 


\section{Foreign immigration in Greece: the looking glass of the international scene}

Perhaps more than any Southern European country, the important role of foreign affairs is one of the most important factors in foreign immigration. Furthermore, according to Baldwin-Edwards (1997), the particular mix of institutional, internal dynamics and external relations is what distinguishes Greek policy from that in the rest of Southern Europe.

The country's geographical position as the south-eastern door of the European Union; the fact that it shares borders with the former Socialist countries (Albania, the Former Yugoslav Republic of Macedonia (FYROM) and Bulgaria) and Turkey (the Mediterranean gateway for Asian and North Eastern African routes, specially from Eritrea and Kenya), makes Greece an attractive country for potential Third World migrants. To undertake a more detailed analysis, all the following dimensions should be taken into consideration: 1) The East-South and the Mediterranean, 2) The North-South divide, 3) the Middle East and the Gulf War, 4) the Kurdish question (for Kurds from Turkey, Iran and Iraq Greece is the first doorway to the Kurdish conflict), and 5) the collapse of communism in Eastern Europe - Rumania, Bulgaria, Ukraine, FYROM (the Former Yugoslav Republic of Macedonia) — and the former Soviet Union.

The creation of the Kingdom of Greece at the beginning of the last century and its expansion in 1947 into today's borders with the construction of the nation-state, did not take into account the dispersion of the Greek populations in the East of the Mediterranean, in the ancient lands of the Ottoman Empire. Therefore, like all of her neighbours, this Balkan-European region has to deal with unsolved problems of its past.

The traditional idea of space is still vitally important in the establishment of today's settlements and migrant networks. The neighbouring countries are strongly represented by migrants in Greece. A good example of the way in which international events can have an impact on immigration can be seen in the case of Albania. The number of deportations of Albanians in Greece grows or diminishes according to the state of affairs between both countries and to the treatment received by the Greek minority at the hands of the Albanian government. As Karydis (1993) suggests, migrants are taken as a political bargaining tool in the Greek-Albanian relationships.

In August 1994, Greece intensified deportations (about 50,000 «illegal» Albanians were deported in one month) after five Albanian citizens of Greek origin were arrested when they were trying to annex the southern part of Albania (Northern Epirus) to Greece, with the knowledge and collaboration of the Greek government. On the other hand, the Greek government insisted on vetoing financial assistance to Albania by the EU if the situation of the Greek minority in that country did not improve (Fakiolas, 1994).

On the other hand, in addition to being conditioned by the Balkan context, foreign immigration is also the result of the regional European and Mediterranean system which has made the country not only undergo many 
socio-economic changes, but also made her become the South-Eastern guardian of Europe, while basing economic development on a cheap foreign labour force.

In terms of the case of Thrace, this " international mirror» can be seen in the way in which ethnolinguistic and religious minority communities like Turks, Pomaks and Gypsies are constructed as social groups, something which can also be seen in the situation of the Greek minorities in Albania and Turkey.

Thus, the very nature of international relations between Greece and certain other states is important in shaping the perceptions that one may have of the different communities, both old and new. In this respect, mention must also be made of the existence of mutual hatred between Greeks and Turks, a hatred which would appear to be widespread, despite cultural and linguistic affinities. The most common stereotype of the Turks in Western Thrace is not framed in terms of criminality or evil, but rather in terms of fanatacism. This stereotype of the Turks is born out of the collective memories of the darker times of the Ottoman Empire, through the stories of invasions and genocides ${ }^{7}$. The genocide of Armenian and Greek communities in Turkey form 1914 to 1924 has been one of the most violent chapters of Turkish history.

\subsection{The demographic hypothesis}

Both Greek and Turkish nationalism have used the issue of demography as a political weapon ${ }^{8}$. In the case of the Greece, the programme for the settlement of Pontios would appear to obey demographic reasons. In fact, I wish to argue that immigration policies towards Pontios pursue a change in the demographic population balance, especially when one considers: 1) the supposedly high birthrates of the Muslim community, 2) the control of political votes in the region, and 3) the "Christian representation» of the population bordering with Turkey?

By analysing the historical legacy left by the Ottoman Empire in order to understand today's Balkan mosaic of communities, I was able to find in the works of Courbage and Fargues (1997) two central points in order to locate these demographic questions:

1) Contrary to what is often thought about polygamy in its Muslim-Arabic form, it is effectively a moderating influence on fertility. Hence, contrary to

7. This hatred and rejection of the «Muslim culture» can be seen in different settings: for example, mosques are not even marked on local maps, like in Komotini resulting in a onesided view of the city.

8. «It is not only for religion reasons that they use Thrace to settle the Pontios, it is also for political reasons. If they have many Muslims they will choose "Muslim politicians"” (social worker 2, EIYAPOE).

9. The surprise was that some of them were not «real Pontios», not only because they found out that many of them did not speak Greek but also because it was not even clear that they were "real Orthodox", this surprise was made clear to the population in Komotini when they became aware of the number of men who were found to be circumcised in Komotini hospitals. In addition to these customs, we should also underline the fact that many of the Pontios who came from Georgia actually have Turkish as their mother-tongue. 
today's tendency which associates Islam and demographic explosion, evidence suggests that in the Ottoman times fertility rates were low among Muslim women when repudiation tended to mean the end of women's reproductive life and also taking into account that Muslim men were mainly soldiers. However, during the first centuries of Muslim domination, together with conversions, demography always played a role in favour of Muslims due to the effects of inter-community marriages. In the East, the law forbade the marriage of a Christian or a Jew with a Muslim woman, but not a Muslim man with a dhimmi (literally, 'people from the book') woman.

2) Demographic change formed part of the strategy of the Ottoman Empire. One of the basic tools for this was the sürgun, the transfer of entire populations by administrative decisions. It was meant to revive devastated populations, especially in Istanbul. It tended to mix populations, both rich and poor, with the policies adopted not only limited to Turks and Muslims. Indeed, Greeks and other Christians were also authorised, and even encouraged to settle in the city.

\subsection{The discourse of homogenisation and nationalism}

The word omogueneis (those who belong to the nation, in contrast who those who do not belong, allogeneis) is very much used for Greek immigration policies directed at the Pontios, despite the fact that Greece was always a mix of different origins. Among the many examples is the case of the 50,000 Jews who settled in Salonika, after being expelled from Spain at the end of the fifteenth century.

Despite the construction of the modern nation states, Hellenism as an ethnocultural entity has survived for centuries, as can be seen, for example, in the case of the "Ethnic Greeks» abroad. Pontios have always been recognised as an integrated part of Hellenism, as the most Greek of the Greeks, trandellines (Greek three times over), considering Greece as their patrida, the land of their ancestors ${ }^{10}$.

On the other hand, Hellenisation, in the sense of adopting a modern national identity has not had to face many obstacles, as there was still no alternative identity in the Balkans. According to Poulton (1997a: 31) while the process of homogenisation in the Balkans has been markedly successful, for example, in transforming multi-ethnic peasants in Greece into Greek citizens, it has failed when faced with the need to bridge the gulf between orthodox Christian

10. "We had a dream to come to Greece, to leave for Greece. But we did not think it would be so difficult to integrate into Greek society [...] It is our motherland here and we have more rights than other migrants, we are refugees from the Turkish genocide [...] What are we supposed to do? Where are we supposed go? To which place? The only place where people cannot tell you to go away from is Greece. Even if it is difficult here, it is our motherland, and that is why we have more rights than the rest. From the other side, comparing our situation with the locals, we should say that Turkish have at least some things, they have land, none of us has land. It is something!» (Pontios association, Tiheró). 
and Muslim communities. Even with the Orthodox Slavs in Northern Greece this policy has come up against a militant minority who refuse to abandon their perceived ethnicity in order to merge into the majority Greek one. The more pressure the Greek state applies to this minority, the more the policy proves counter-productive.

As we have mentioned above, the host society has no social integration policies, only assimilation ones, that is specific policies which deal exclusively with Pontians. Nevertheless, it is not just the Greek government that has no experience in the field of social integration policies for immigrants, but even the international organisations like the International Migration Organisation in Greece are only now trying to set up a programme aimed at the cultural aspects of the social integration of migrants.

The political parties in power together with the press have based their discourse about the new immigration flows on just two stereotypes: competition for existing jobs and responsibility for the increase in crime rates, although the former greatly benefits the Greek economy (Papantoniou et al., 1996: 148). There is a strong sense of nationalism, which some sectors interpret as threatening hostility to minority groups.

The model chosen so far is based on a representation of an ethnically homogenous society, with common traits not only in language and culture but also from a generalised myth of being descendants of an old civilisation, in this case, the ancient Greek one. This is partly what typifies the model of a closed society based on the Greek ethnos (orthodox religion, national spirit and Greek language) and on a Gastarbeiter regime (accepting immigrants on a temporary basis). In short, a restrictive approach which does not leave enough space for cultural difference, whether in schools (where secularism does not exist) or in religious practice (where mosques are not officially allowed like in the case of the city of Athens).

The nationalistic discourse represented here can be situated across three dimensions: 1) an extending «albanofobia», 2) resentment towards the Turks (especially after the Imia-Kardak crisis in 1996), and 3) glorification of the ancient past; all of which deeply influence the way the «foreigner» is socially constructed. According to Papantoniou et al., (1996), this political and nationalistic element is very much present in the discourse of the authorities and in discussions about foreigners in the Parliament (see Parliamentary Proceedings of 28/1/91 and of 18/3/94). From the very beginning the building of the modern Greek nation-state has been in contradiction with its own base, Hellenism. This contradiction can be seen in many spheres of society, but perhaps it is through analysing immigration policies in the Thracian case that one can see its contradictions more openly.

\section{Old communities (Turks, Pomaks, Roma and Pontios)}

We use here the term "old communities» to refer to both the old minorities who have been living in Western Thrace for many years as well as the newly 
arrived ones who are also «old» because they are considered part of the ancient Greek diaspora.

Pomaks are mainly concentrated in rural areas near the Bulgarian border. The Pomaks resident in Greece do not want to be considered Bulgarians nor do they feel Greek because of the Greek phobia towards Muslims. However, since they do not have a written language, they use the Turkish schools and end up defining themselves as Turkish as a reaction to the hostility the orthodox community feels towards Muslims. They now have EU programmes directed at their needs, but these programmes actually use the Greek alphabet. In Bulgaria on the other hand, they are officially known as the Bulgarian Muhammadians or Bulgarian Muslims, a confessional minority of 220.000 people.

Pontios are part of the old Greek diaspora abroad who for political or economic reasons had emigrated from the region of Pontos (north-east Turkey) during the thirties and after the Second World War to the former soviet Republics of Georgia, Armenia and Kazakhstan. However, in 1923 a major part of the Greeks from Pontios and from the Caucasus settled in Greece, coinciding with other refugees from Asia Minor, Eastern Thrace and Bulgaria. They settled together according to their village or region of origin, often using the same name as the original by preceding it with «new», and using houses and lands abandoned by Muslim (Turkish or Bulgarian) families. In the Ottoman context, the «real» community for the majority of the population was the village, whose inhabitants one knew personally, while the «imagined» one was the religious community as in the millet system. In the post-Ottoman period the "nation» (however defined) competed for allegiance as the «imagined» community (Poulton, 1997a: 28).

\subsection{The problem of terminology}

The problem of terminology centres on how to give names to the different communities living in Thrace, which has also caused open controversy on all sides involved (see figure 1, p. 133). The different possibilities are presented here according to the distinct type of criteria:

1) Religion and not ethnicity would be the criterion used to define who is a Turk and who is a Greek.

It is also interesting to see how in border territories identities become specifically religious, such as the case of Sebta and Melilla, the Spanish territories in North Africa, where local population make the distinction between "Musulmanes and Cristianos».

2) As a result of an state-sponsored policy of assimilating the Pomaks into the Turkish population, particularly through the introduction of compulsory schooling in Turkish (and subsequently, using Turkey as a kinstate).

3) The self-definition of communities. 
Figure 1. Terminology used to describe the different communities living in Thrace.

\section{Official definition}

MUSLIM (Musulmanos)

- The Greek government points to the Treaty of Lausanne which speaks only of a «Muslim minority».

- Official use for identification cards use the following type of categories: PomakHellenic-Muslim, Roma-HellenicMuslim.

PONTIOS (Greek from Póntos, in the Black Sea)

RUSO-PONTIOS

PALINOSTIS ${ }^{* *}$

\section{Other definitions and self-definition}

\section{TURKISH (Turkicó)}

- Turks, Pomaks, Gypsies are self-considered part of this group. Considered Muslim by the official category, Turkish by their self-definiton.

- It is illegal to use the word «Turkish»" as an adjective to describe an association. Left-wing Greeks would use the term Turkish and the Right the term Musulmanos.

- Local Greeks use the division between «Ellenikó» (person of Geek origin) and «Musulmano".

- Turkick, which is not used by the people either by the government means the population outside of Turkey which identifies themselves with Turkish language and Turkish culture. Especially when considering the diversity of populations in the Ex-Soviet Republics.

- The Arabic term Umma would include the only religious and non-territorial definition of all Muslims living in the world.

- In today's Turkey the word "Turkish» also implies being «Muslim».

\section{RUMEI}

- Historical self-definition: «Rumei», in the Soviet Union they were called SovietGreek $^{* * *}$ or Greki. Rumilia was the European part of the Ottoman empire.

- Neither Turkish, Russians or Georgians have been able to assimilate Pontios.

- They use the term «Rumei» and is opposed to "ndopios» (locals, people who were born here, natives), and they are usually called in Greece, Ruso-Pontios.

Source: Author's analysis.

* «Turkey is our mother and Greece our father». They consider that they have «returned» to Greece, considered as their motherland, after the collapse of communism and the dismantling of the Soviet Union.

** Greek immigration of populations like Pontios, who had never previously resided in Greece are called palisnostis, meaning «returned». The use of this term traces the return of Ulises to Ithaca. The verb Palinostó means to repatriate, from Pali, again, and nostos, return to the homeland. Therefore they are not considered metanastis (immigrants).

*** «Our heart is Greek and our head is Russian». 
As in the rest of the Balkans, Muslim communities face a problem compounded by the fact that they are both an ethnic and religious minority. In the region, the presence of about one million Muslims creates a responsibility for Turkey as a neighbouring Muslim country, a responsibility which is magnified by the historical legacy of Ottoman rule in the region (Taji-Farouki and Poulton, 1997: 2-3). To understand this situation one must look again to the historical background, the legacy of the Ottoman rule, in which the Balkan Christians, as disadvantaged citizens, developed both a suspicion and dislike of the Turks and Islam (idem: 7). The long period of Ottoman rule and the millet system nurtured a strong sense of belonging, which was determined exclusively by religion. In this context, the cohesive nature of Islam as a social force emphasising the notion of a universal Islamic community or umma reinforces this. The Muslim community in Thrace consists mainly of ethnic Turks, Pomaks, and Roma, and is predominately Sunni. Nationalism seems to end up legitimising the social exclusion of the Turks (considered by themselves as a unique group, a single Muslim community). Indeed, most «Muslims» identify themselves as Turks, regardless of their ethnic origin.

The Greek government recognises only one minority ${ }^{11}$, the "Muslim» minority living in Thrace and protected under the 1923 Treaty of Lausanne. Even today the terminology used when describing minorities varies according to place as well as to the political identification of the people who use the term. According to the official version, identifying the minority "Turkish" is considered illegal and may lead to prosecution. "Turkish» associations have been dissolved, as can be seen in the example from 1987 when the Supreme Court irrevocably dissolved the "Union of Turkish Teachers of Western Thrace» and the «Union of Turkish Youth of Komotini». This defense of the Muslim term can be clearly seen through the following statement:

In Greece we do not speak of a Turkish minority; we call it the Muslim minority. We feel this term, Turkish, gives them an ethnic Turkish character, while downgrading other elements that are not Turkish (such as Pomaks and Gypsies). We have ratified the code on ethnic self-identity. We will wait for the decisions of the European Court of Human Rights. [...] We would like to see what the Commission and the Court of Human Rights say on whether we should use the term Turks (Kambellis, state-appointed secretary for Thrace, HRW, 1998: 12).

In contrast Rozakis, vice-president of the European Court of Human Rights in July 1998 said: «These complex elements of origin, religion, and linguistic options, as well as of cultural and political ties, make this minority an ethnic minority, and not solely a religious one» (HRW, 1998: 14).

11. Since 1951 there is no data on national/ethnic origin on the Greek Census. According to the 1951 there were 92.443 Turcophones, 7,429 Gypsies, and 18,671 Pomaks, for a total of 118,533 (HRW 1998: 9). 
One subject that has been taboo is that of talking about the existence of different communities. As seen in the interviews, very rarely is the issue of the existence of the different communities approached directly. The majority of Greek institutional actors in particular treat it in an elusive manner.

The Pomaks, due to their geographic location in the mountainous ColdWar boundary between Bulgaria and Greece, seem to have developed a separate identity from the rest of the Thracian communities. The Pomaks of the southern Rhodope mountains have tended to live in areas where freedom of movement is resticted, marked by the border which represented the NATO/Warsaw Pact confrontation. The most important Pomak villages are: Miki, Roma, Therme, Melivia, Oreon, Kiknos, and Echinos. Other Pomaks live in Evros, in Kehros and in the small village of Organi. Compact Pomak villages are organised around a tightly-knit family and kinship structure, working in an economy based on small-holdings, where families earn a living from a variety of sources such as wage labour and crops.

The various attempts to define the Pomaks raises the main points of controversy in what may be called «Pomak debate»:

1) Are they, in historical terms, an «autochtonous» or an «immigrant» (Turkish) population?

The Greeks would claim that the Pomaks (Slavs converted to Islam) have more in common with the Greeks than with any other groups, a debate which can be traced back to the whether Philip and Alexander the Great were real Greeks or were actually Pomaks. There are those who sustain that the Pomaks are different to the Turks and that they have a common Greek heritage, that they are descendants of the native Greek population, and that linguistic affinities between Pomaks and Greeks can be found. Others would say that those affinities do not necessarily mean that they have originated from that area; an area — Western Thrace - that has seen many migrations during both the Byzantine and the Ottoman eras.

2) How did they convert to Islam, voluntarily of by force?

3) Should the matter be discussed in the same cultural context as other Balkan Muslim populations that include the Turks, the "Turkish» Gypsies, the Muslim Albanians, the Bosnian Muslims and others, or in the context of the ethnic Greek or Bulgarian populations? Some people would say that they have been the victims of manipulation by the Turks to impose the Turkish identity on all Mulism living in Greece.

4) They have become object of a nation-state conflict, having been proclaimed by the Greeks to be Hellenised Thracians, by the Turks to be Turkish preOttoman nomadic tribes, by the Bulgarians to be Bulgarians and so on. (The acceptance of the Pomaks as descendants of ancient Thracians has become the object of heavy criticism from Bulgarian nationalists. In general terms, the central point of the debate is revealed by a passionate search for «evidence»). 


\subsection{The reproduction of the millet system}

They were not citizens, they were umet of the empire

(interviewee).

From the fall of the Byzantine empire (1071) until First World War, the Turks had gradually established a multinational and multiconfessional state in the East of the Mediterranean, although it must be remembered that the confessional minorities had never formed nations in today's sense, that is with a territorial attachment. Different minorities benefited from the institution of the millet. Through it the Ottoman Empire delegated its authority to a spiritual representative of each one of the recognised communities. Questions related to personal legislation, marriage, school and all family affairs were competence of the millet. Leaders of the various millets enjoyed wide jurisdiction over their members, who were bound by their own regulations rather than by the Sharia (Islamic law, which deals, especially, with family issues). The Ottoman State treated the millets like corporate bodies; Greeks were traditionally a millet very close to the upper hierarchies of the system. It encouraged the perpetuation of their internal structures and hierarchies by dealing exclusively with their leaders and not individual members. These structures included educational systems specific to each religious community. The millet system of the Ottoman Empire became established as the prime focus of identity outside the family and the locality. However, if during the time of the Ottoman Empire an association of people and territory did not exist, the concept of the nation-state would imply just the opposite. Hence, after so many centuries of Ottoman rule, the construction of modern national identities in the region provoked a confusion in the use of the concepts of religion, ethnicity and citizenship (Poulton, 1997a).

As we have already seen through "the demographic hypothesis», demographic differentiation of Ottoman society took as its sources the social stratification instituted by the millet system. This society was highly hierarchical, placing military functions at the top. The Muslim majority did not exercise the same activities as the Christian and Jewish communities; for example, agriculture and military activities were essentially reserved for the Muslims, while industrial and commercial exchange and services were undertaken by the minorities (Courbage and Farges, 1997).

The millet system was mainly based on a non-assimilative and «multinational» approach. The empire was divided not along ethno-linguistic lines but by religious affiliation. Muslim tolerance was manifested by the acceptance of large numbers of Jews, notably the Ladino speaking Sephardism, expelled from Spain a the end of the fifteenth century, many of whom settled in Salonika, which became a predominantly Jewish city (Poulton, 1997a).

In present-day Greece, and particularly in Thrace, as a legacy of the Ottoman regime, one can see modern reproductions of the millet system, whereby religion defined communal identity rather than ethnicity of language. 


\subsection{The Treaty of Laussane}

The Treaty of Laussane is the main legal framework protecting the «Muslim» community living in Thrace. The Lausanne Treaty of 24 July 1923 laid down further guarantees concerning the rights of minorities, and used the term «Muslims of Greece». The Treaty put an end to the Greco-Turkish War, secured Turkey's present borders, and obliged both countries to respect the rights of the Greek minority in Istanbul and of the Turkish minority in Thrace concerning religious practice, the use of language including in primary schools, and control over religious affairs.

In January 1923, Greece and Turkey signed the Convention Concerning the Exchange of Greek and Turkish Populations. Turkey demanded the repatriation of ethnic Greeks residing in the Anatolian areas of the former Ottoman Empire in exchange for the return of the ethnic Turks living in the Kingdom of Greece. For its part, Turkey allowed those ethnic Greeks residing in Istanbul before October 1919 to remain (around 110.000), along with the Orthodox Patriarchy, while Greece was to allow a similar number of ethnic Turks (between 105.000-120.000) to remain in Thrace (HRW, 1998: 7). People refer to it as to the "population exchange»; the composition of today's minorities could thus be date to this point in history.

\subsection{The EIYAPOE programme for Pontios}

During 1988 and 1989, the need to implement a specific refugee policy for Pontios became apparent to the Greek government. As part of the policy, an agency (known by its short name, Idrima, meaning 'foundation') was set up in December 1990 to pursue a strategy of territorial implantation in the marginal areas of Northern Greece, which basically corresponded to a policy of Hellenisation of Macedonia and Thrace. This agency will be here used in the text by the abbreviation EIYAPOE (Ethnikó Idrima Epodohis Apodimon \& Palinosteton Omogenou Elinon, National Foundation for the reception of expatriated Greeks).

The programme covers all the stages of the arrival, from the first reception centre (only present in Thrace), at which the immigrants arrive from their countries of origin, to their definitive settlement. The EU and the Greek government co-finance the measures. The programme also used to include sub-programmes such as the teaching of the Greek language and promoting enterpreneurship, although subsequently only housing benefit was provided.

The Ministry of Foreign Affairs has overseas delegations in the ex-Soviet republics (and also in Northern Epiros in Albania) to recruit those persons to be located in the main reception and settlement programme in Thrace (with its main delegation in Komotini). The main settlement centres are based in Kabala, Xanthi, Rhodopi (settlements of Komotini, Sappes), and Evros (settlement areas of Alexandropouli, Orestiada, Tiheró, etc.). The programme 
consists of five different phases ${ }^{12}$ : information centres, reception centres (short stays), reception for settlement, rented housing and purchased houses. In phase two, health services and the teaching of the Greek language are also considered, while in phase three, the immigrants are housed in pre-fabricated homes. In phase four, they are entitled to cash or vouchers as well as to some specific medical assistance. In this phase, family problems related to children's education (with no extra budget allocation) are dealt with, and access to social workers and contacts with other services of the agency are also established. However, the main problems observed with this programme are: 1) the lack of concern for insertion into the job market (with the result being the Pontios do not want to go to Thrace, prefering instead the big urban centres like Athens and Salonika), 2) the lack of prevision for rotating migrations ${ }^{13}$, and 3) the lack of a wider approach based on social integration (which is also related to the mismanagement of public funds).

The only service for a specific population group is the EIYAPOE programme, while all other communities must make do with general services, apart from primary education and issues concerning family law. Within the Pontios groups there is a difference in the level of services provided for the flows of migrants that arrived at the very beginning of the nineties and those of more recent years, while the same differences also occur across different nationalities (for example, in the case of Georgians and Armenians, various migrant networks are constructed, with a high degree of solidarity especially present among Armenians). Receiving some social services like those related to heath can be difficult given the lack of nurses that speak Russian. Notwithstanding, an alternative option, that of the informal help of the members of the community, seems to be frequently available. Another problematic question is that related to the teaching of the Greek language, in that classes are no longer financed. Thus all services have been cut except those related to housing, the final goal of which is the provision of permanent accommodation.

\section{Family context and excluded women}

There are three basic institutions for the regulation of social life: school, work and the family. The institution of the family shows us the different functions of the diverse itineraries of the members: where they have been born, where

12. Logically, official documentation (residency, nationality, etc.) is also prepared during the first phases. The programme would appear to work quite quickly in this respect: «For Pontios we take four or five months in order to get Greek passports (Pontios association, Komotini).

13. "There are about 22.000 Pontios in Thrace but 100.000 in Greece. However, then they move to Athens to find a job and live a better life, even if they own a house here in Thrace. They do not only emigrate there, they also go to Germany, Holland and Cyprus, and they even move again if they fail to find work or loose their jobs» (Pontios association, Komotini). 
they have been socialised, their sex, age, social and professional status and their immigratory project. The family is a key factor in the process of the integration of immigrants and in the formation of community networks. It is in the differences between family members that we are able to see how policies —or the lack of policies - affect people differently: men and women (the sexual division of labour and also the female dependence on men's work permits), and children (their legal status and their education). Here we see how cultural differences and also differences in family structures lead to different demands on social services. The programmes for Pontios are defined around a family-orientated approach where housing is its only expression. Even if the family is always the basic unit of the targeted programme, there is never especial attention to women's issues. However, there is a special concern for the cases of single-parent family units with small children. Acccording to the social workers of the programmes, the persistence of single-parent families is very high among the Pontios they deal with.

In the case of Greece we can see how, as a result of modernisation, traditional forms of family solidarity and paternalistic structures decline without being substituted by alternative forms of social protection, given the weak development of social policy. This implies a high risk of marginalisation for a number of social groups. Family networks for getting jobs and supporting the unemployed are in this respect important, although they differ according to the community in question. Traditional regulation of communities such as those related to social control and tini (honour) are still very important in rural Greece for both women and men. Not only for Greeks but also for Turks, Pomaks and Pontios the code of honour is one of the foundations for a highly cohesive community, and is a means of keeping and expressing their own identity. Seen mainly as traditional communities, they also practise arranged marriages, early-age marriages, etc. "We have Pontios who belong to traditional families and others who do not. Within the latter, women are much more free, while women from the former group have many children and do not work outside the house» (social worker 2, EIYAPOE). Furthermore, "traditional Pontios» are thought to be the «true Greeks», like the Greeks who emigrated to the United States. For Pontios, family cohesion seems to be the basis of their identity, «maintaining our traditions is a result of our way of life, it is a way to protect the community, and in the Soviet Union it was the only chance to maintain our language and traditions" (Pontios Association, Alexandropouli).

Most of the interviewees highlighted gender issues while differentiating communities. Particularly the way in which it is through the family structure and the organisation of gender roles (inside those structures) that the division of the cultural components of the communities and the construction of the stereotypes for each community are based. It was from this contrast of gender roles that the idea of the Greek community and the Turkish community was constructed. The latter would be defined by relegating the female public presence as a typical feature of Muslim dominated societies. On the other 
hand, the Muslim and Turkish family can also be understood in terms of a model of cohesion and as the basis for the construction of economic networks, especially effective in searching for jobs. In terms of the model of the urban Greek family, it is commonly assumed to be a very united model of family, based on small entrepreneurial activities and aspiring to urban middleclass lifestyle and values (see Fakiolas and Maratou-Alipranti in this monograph for more details).

From the Greek point of view, it is often gender inequality that stands out in their discourse on "Muslim communities». As such, it would not be the state which oppresses the minority but it would be the family structure which mainly oppresses women and relegates them to a low-level of educational achievement and to confinement to the home sphere. Furthermore, the Greeks interviewed consider that this oppression is in no way contradictory as it is fully legitimised by the Koran. Men are seen here as the basis of this oppression within the family structure and who, in contrast, «enjoy complete freedom to spend part of their leisure time with the Russian (Pontian or not) prostitutes».

In terms of the labour market, Pontian women seem to perform the traditional female tasks of private cleaning services and looking after children that Albanian women tend to assume in the rest of Greece. However, they carry out these tasks only in the most urbanised areas. Thus, in the rural and semi-urban settings the cleavage of genderised occupations for migrants seems to have a different function. Pontian men, although quite well qualified, mainly work in the building sector as plumbers or electricians. The situation in Thrace is by no means comparable to the situation in Athens, where one can find a clear distinction between foreigners and nationals. For example, in Athens the children who beg in the streets are Albanian, while other street vendors (of tissues, flowers, etc.) are also foreigners, this division in the occupational structure is more diffuse in the Thracian case.

As regards to the status of Pomak women, gender discrimination seems to be double that suffered by Greek women. In this region where tobacco is still cultivated in the traditional manner, with the work organised into household units, gender divisions are also seen in agricultural tasks as well as in family roles. Following on from this, "modernisation» also affects men and women in a very different way. In this Pomak society, a growing number of boys have now access to secondary education, which as a result introduces changes in the traditional gender division of labour. However, these changes end up reproducing the previous patterns of the division of labour based on gender, between those jobs related to agriculture (for Pomak women) or those related to culture (for Pomak men). Besides, the increasing role of women in the growing of tobacco tends to devalue these agriculture jobs, which only reinforces women's status of inferiority (Vernier, 1981: 140). Furthermore, the lack of places in minority high schools disproportionately affect girls: those who go want to continue must go to Christian schools, and a Muslim-minority family would rarely allow the female child to attend a non-Muslim school (interview to a Pomak leader, by HRW, 1998: 29). 
In terms of the status of Turkish women in Thrace, it became apparent in various interviews that education creates divisions along lines of gender and between communities: "I think the main difference between women's roles in the different communities comes down to education. Turkish women are more closed than Greek women; they also tend to do most of the agricultural work, in the fields with the tobacco crops and cotton. The whole family works in the field» (Minority Scientist Association).

In terms of family law, the Sharia is combined with Greek law, depending on the case. Family formation is here a good indicator of the complex social relations between communities. Mixed marriages are still unheard of in Thrace, at least for partners belonging to different religions.

\section{Different perceptions of social rights in Western Thrace}

Petmesidou (Petmesidou et al., 1994, 1996) underlines the divergent transition paths across Europe according to historical trends of socio-structural patterns, the patterns of conflicts and contradictions related to the variations of welfare capitalism in North-West Europe, and the State/paternalistic structures in South. Within Southern Europe, travelling along a path from the Northwest to the Southeast, significant differences are observed as to the economic structure, the state-civil society relationship, and, particularly, to the strength of civil society vis-à-vis state authority and interventionism.

In the case of Greece, the rapid change from agrarian structures to a service-oriented society has led to weaker collective forms of solidarity and universalism in welfare provision than in the rest of Southern Europe. In the South-East (Greece and other Balkan countries) the tradition of contractual relations, collective solidarity and active civil society is weakest. Hence, statism and clientelistic forms of social organisation typical of Southern Europe are, according to the author, accentuated as one goes further South and Southeast. In contrast with the role of the Church in the countries of the Latin Rim, where Catholicism has strongly supported subsidiarity in the provision of welfare services ${ }^{14}$, which in turn enhances the role of the family in welfare delivery as well as promoting voluntary action in social protection, Greece suffers from a lack of voluntary religious institutions acting as providers of welfare.

In the context of Thrace, the urban-rural cleavage neatly reflects the socioeconomic exclusion of Pomaks and Turks, both of which enjoy generally poorer living conditions. The urban-rural cleavage also reflects the division between urban and rural occupations (where the vast majority is in the hands of Muslim families). Other divisions can also be found: for example, the Turks work in the weekly open-air markets, while Greeks own the most modern and expensive fashion shops.

14. "The Church in Greece, compared to that of Italy, is weakly developed in terms of social welfare. Besides, the political relation is not the same, here the Church is very conservative and does not have such a political role» (mayor of Tiheró). 
On the plains to the south of Xanthi, Komotini and Sappes one finds Muslim Turkish villages, while the Pomaks live in the mountainous north. The Christian settlements are primarily distributed along the coastal zone of these prefectures, although the prefecture of Evros is almost exclusively made up of Christian settlements.

In Komitini the neighbourhoods are highly segregated and it is not difficult to differentiate between Greek middle-class areas, Turkish working-class areas and new areas of Pontios settlements. In addition to the spatial segregation, one also notices differences in the type of contruction: the Turks, for example, build low, white houses with small windows, often with satellite TV on the roof. The Gypsies are found on the outskirts of Komotini, in an area with muddy roads where the small children of the neighbourhood seem to be the guardians of the area. The Turkish-Greek divide of the city represents two different societies with weak or non-existent personal relations between the two.

In Sappes, the division of the space is also quite marked, with the Turks on one side, the Greeks on another, the Pontios on another, in addition to the military sector. The spatial organisation of the different communities is really very illustrative of their socio-economic reality. Now all of them also have access to satellite TV, except the Pontios, who are currently trying to organise a system in order to receive Russian TV.

In terms of social welfare administration, mention should be made of the fact that the Greek state has yet to start a decentralisation process, while at the same time Thrace suffers considerably from central administration neglect. Hence, it is difficult, if not impossible to speak about real social policies or the interaction of actors working in welfare policies; instead it would be better to talk about ad hoc services. For example, the «dimarhia» (municipality) of Komotini cannot offer social services, the "peripheria» (regional administration) is an executive organ of the state (which has not really developed social services in Thrace), while the prefecture has no resources to develop policies. The regional level was only institutionalised in the early eighties, with pressure and funding from the EU, but offers no social services. The regions administrate EU money, being active in roads infrastructure, vocational training and issues concerning social exclusion ${ }^{15}$. In terms of the development of rural areas, the EU programme for Mediterranean regions has been set up for this purpose. The regions implement initiatives related to employment initiatives based on target groups (e.g. Integra programmes), and among those groups the "Muslim community» is included, as became apparent in our fieldwork.

There are no civil servants working specifically on social services except for social workers. At the local level, the only service offered is the Kappi ${ }^{16}$ (daycare centres for elderly people). However, change is afoot, with nursery schools,

15. It must be remebered that all of the territorial extension of Greece and Portugal qualify for EU Structural Fund assistance see http: //www.europa.eu. int

16. KAPH. Kentro Anithtis Prostaseas Elikiomenon. Open day care fot the elderly and social/communication centre. 
for example, soon to become the responsibility of the municipalities, and there is a plan for housing policy to follow suit, although nothing has been done yet. The latter still functions through an inter-personal and clientelistic system. Overall, municipalities still have very little local power, above all due to the highly centralised political system. However, timid progress has been noticed in the process of the empowerment of the municipalities, together with the beginnings of the development of social services at the local level (which are today still non-existent, except from the work of a few social workers).

\subsection{The perception by the Greek administration}

This perception is based on a very centralised model that leaves little room for the development of state-civil society relationships, with the result being that the civil society is at a disadvantage vis-à-vis state authority and interventionism. As mentioned above, Greece shows weaker collective forms of solidarity and universalism in welfare provision than the rest of the other countries in Southern Europe, which can be seen very clearly in the case of Thrace.

Concerning immigration and minority issues, we should say here that both issues, those dealing with immigration policies and the special implementation of social integration measures for Pontios population and those dealing with the minority, operate at the level of the central administration:

The affairs of the community depend on the peripheria. Although the nomarch (prefect) had some power when they were elected for the first time, the central government took this power away and gave it to the peripheria (Minority Scientist Association).

One of the first perceptions to be underlined is the underdevelopment of Greek social services compared to other European counties, with this being especially true in the case of Thrace: «In Sweden, $40 \%$ of the social service budget goes on benefits, the other $40 \%$ goes on education, and $20 \%$ on building. In constrast here, in places like Komotini, $96 \%$ of the budget goes on water treatment for the city, so we are far away from having these services» (mayor of Sappes).

The only specific programme for foreigners is the EIYAPOE, all the rest have to deal with general services for all. Notwithstanding, as already mentioned, this programme covers mainly housing benefits and does not attend other important problems such us the gap between offers of employment in the rural sector and the industrial skills of the Pontios. However, policies for Pontios are limited to the building of houses for their settlement: «It is easier to give them homes than to give them jobs. The result is that all of them go to Salonika. We have no factories here» (social worker 2, EIYAPOE).

As regards to the relation bewteen the administration and the Church, it should be pointed out that the Eastern Orthodox Church maintained its privileged status as the only official religion in Greece, creating a number of dis- 
advantages for other religions. In Thrace this was especially so for the Muslim religion, which has always been presented in the light of a threat of Turkish intervention as well as a threat to Greek identity, of which the Orthodox religion is so much a part.

\subsection{The perception by the Turkish associations}

The interviews with the representatives of Turkish associations mostly complaints of discrimination towards the minority in terms of the loss of citizenship $^{17}$, the non-observance of the protection of the Laussane treaty (as well as criticising the Greek government for being a "theocratic state»), all of which encourage discrimination in the sphere of education and in the labour market. Responsibility for this discrimination would appear to rest with the Greek government, especially the ministries of Home Affairs and Foreign Affairs, both of which are behind the policies of demographic homogenisation. Nevertheless, other examples of important restrictions that the minority has suffered before seem to have diminished over time:

Several of the most egregious laws, such as those that deprived ethnic Turks of basic rights of property and occupation, have been repealed. [...] There have also been efforts to improve education, such as creating a quota for ethnic Turks in the state university system. [...] The 1994 decision to allow the election of provincial governors (Nomarcs) and municipal councils appears to be a positive step [...] Unfortunately, the Greek state changed the boundaries of two provinces to prevent the election of an ethnic Turkish or pro-Turkish governor from an exclusively ethnic Turkish electoral list (HRW, 1998: 3).

In contrast with the specific services for Pontios through the EIYAPOE programme, the Turkish community enjoys no special treatment in terms of spe-

17. Article 19 of the Citizenship Code empowered the state to strip non-ethnic Greeks of their citizenship if they had permanently settled abroad with no intention of returning to Greece. Article 19 of the citizenship law, which had sometimes been used arbitrarily to deprive non-ethnic Greeks of their citizenship, was finally abolished. The article stated that a person of non-Greek ethnic origin leaving Greece without returning could be declared to have lost Greek nationality.

According to government statistics, 60,000 Greek citizens, mostly ethnic Turks, had been deprived of their citizenship and had become essentially stateless since the introduction of article 19 in 1955. While the apparent intention of the law was to force those deprived of citizenship to migrate to Turkey or Germany, as many as 1,000 former Greek citizens remained in the country after their citizenship had been revoked. As a result, they faced difficulty receiving social services such as health care and education and were denied the rights guaranteed in the 1954 U.N. Convention Relating to the Status of Stateless Persons ratified by Greece in 1975. Moreover, the abolition of article 19 was not retroactive: those who had their citizenship revoked prior to the law's adoption have not been able to have their citizenship reinstated. In January 1998, the state finally gave 150 stateless persons identity documents, which allowed them to travel abroad, as well as to receive social benefits and education (Greek Helsinki Monitor and Minority Rights Group, 21-1-98). 
cific policies, apart from those related to the rights guaranteed by the Treaty of Laussane, which are not always respected, with the election of muftis and waqfs being an example: "They only use the money for schools and to repair mosques, there are no other services» (Minority Scientist Association). The interviewees consider that the Greek adminstration has not formulated any public policies, and even their own associations, do not have any strength to work on public policies: «Associations here are not real actors. If the associations had more power [...] But they are definitely not significant actors» (Minority Scientist Association).

A 1990 law granted the state wide-ranging powers in appointing the mufti, the community's religious leader who also serves as an Islamic judge in civil matters, violating one of the pilars of the Treaty of Lausanne that allows for the minority to manage its own religious affairs. The same can be said of appointments to the private charitable foundations, known as Vakiflar, that support educational and religious institutions (HRW, 1998). The muftis are nominated by a consensus of the ulema but are dependent on central government, more specifically the Ministry for Education, and religions other than the Orthodox Church and are subsidised by the state. Under the provisions of the decree 2345/1920, the Muslim community elected its own representatives, however, the military dictatorship of 1960-74 ended this, and despite the return to democracy government appointees continued in office (Poulton, 1997b: 87). There are now in Thrace two muftis that can be elected by the state. The one in Komotini has been elected but the one in Xanthi has been appointed. This issue goes against the Treaty of Lausanne and the country's international undertakings, and indeed goes beyond the restriction regarding the appointment of muftis, extending to the administration of waqfs and religious teachers.

The main areas identified by interviewees as areas where discrimination towards the minority takes place were in education and in the job market. The Turkish community complains that youngsters have been forced to leave, and that young people who study in Turkey are unable to come back to their places of origin because they have no possibilities of finding jobs to match with their educational level:

Most people work in the fields, with tobacco or cotton. People who graduate from university have no place here [...] There are no minority employees in the administration, only in manual tasks and cleaning (Minority Scientist Association).

If the Turkish population are denied administrative and secretarial positions, then in less skilled jobs they must compete with the newcomers:

If you go to a workshop in Komotini, the Turkish are always the workers, not the bosses. Now, they are slowly starting to be replaced by those coming from Russia, who are willling to work for low wages (Pomak teacher). 
Education emerged as a focal point in the interviews, with the very low level of education among the Muslim minority in Thrace explaining their overrepresentation in low-status jobs. Not surprisingly, education is given a key role in the needs for changing the current situation:

The key to understand everything is education. First comes education and then the rest of the problems follow. This also explains why the women are not «modernised». On a scale of 1 to 20 points, we could say that the first 10 points correspond to education, while the remaining 10 correspond to economic reasons (Pomak teacher).

Human rights violations in the field of education affect the largest number of individuals and have done the most to foster Turkish minority's relative underdevelopment. Schools are overcrowded and poorly funded compared to those attended by ethnic Greeks. The quality of teachers is low (HRW, 1998: 3).

It is worthwhile to introduce here the problem of the education of Pomak rural populations. In the case of the Pomaks, neither the Greek government nor the Bulgarian communist regime did very much to promote their cultural specificity. Consequently, the Greek state had, supposedly, left open the possibility of pan-Turkish propaganda through the learning of Turkish language. This is why now Pomak children speak their Pomak mother tongue at home -Pomaká - and are taught Turkish and Greek in minority schools. Satellite television broadcasts from Turkey also help to preserve and develop Turkish culture among Muslims in Greece. Therefore, television here has a crucial role in preserving and strengthening cultural differences; while other media like newspapers and radio stations should also be mentioned (like Işik FM). Associations are divided along different lines (religious — secular; left wing communist - the right wing linked to Nea Democratia, each with their own local newspapers and gazettes). In a city like Komotini there are 10 Turkish newspapers, more than Greek newspapers.

As regards specific services for the Turkish population, their absence is noteworthy. The Turkish community must use the services aimed at all citizens, without receiving any special attention:

Most of them have problems with the language, they cannot speak Greek, it's difficult for them to go to the Kappi (open care centre for the elderly) and to have a relationship with the rest of the people (Minority Scientist Association).

Finally, when addressing the issue of public policy design regarding differences between populations a key question should be asked. That is whether policies should actively recognise and support different cultural groups by means of public policies without contracting individual basic rights or wheter policies should be based on individual rights and state neutrality with respect to cultural membership). In that respect a strong anti-assimilation posture is often expressed by the minority, while trying to avoid the risks of ghettoisation: 
We don't want assimilation, of course, nor do we want ghettos. We are a different nation with a different religion, a different culture; we want things to be as laid down in the Laussane treaty. We are not part of the Greek nation, but of the Turkish nation and we are Muslims. And we were given these rights by the Laussane Treaty. We want everything that it is in the Laussane Treaty (Turkish journalist).

Thus there has been no policy explicitly aimed at them, not even from the European programmes:

There are no EU programmes for the minority. There are some programmes for the mountainous areas, for the Pomak-Turks. But they try to make them feel as if they were a different nationality, so the people who live in these areas have rejected these programmes. Because in everything, in every step, there is a political plan [...] This terminology, to separate the minority into three nationalities is very dangerous, and the minority rejects this policy (Minority scientist association).

They are using this money especially for ethnic purposes, to divide the people. Divide and rule. [...] If they separate them into small groups it becomes easier to assimilate them, and the second reason they divide in groups, is to get funds from the EU. [...] The Pomaks work with animals and with the tobacco crops. But if the EU makes cuts in subsidies for tobacco, half of the families will collapse. It is the only thing you can cultivate in the mountainous areas (Pomak teacher).

\subsection{The perception by the Pontios associations}

The perceptions by Pontios mainly relate to the results of the EIYAPOE programme, often emphasising the paternalistic stance of the Greek administration towards them, and they also reflect the feeling that they are the victims of a highly bureaucratic and centralised system of administration.

Housing policy has been seen as the main goal of the EIYAPOE programme, and a key issue for the social integration of Pontios. The housing programme started with the reception centres, folllowed by prefabricated buildings, and finally came purchased houses, often using models of spatial segregation.

As already mentioned above, the main problems observed with this programme are those concening insertion in the labour market, emigration of Pontios to bigger urban areas and the lack of a wider social integration approach. Concerning the insertion into the local labour market, certain issues should be considered especially problematic. In an area characterised by its agrarian economic structure, there is little call for a skilled industrial labour force and much less one specialising in heavy industry. In addition, unlike the Attiki region (see the case of Athens in Fakiolas and Maratou-Alipranti, in this monograph), in a rural family setting there is little need for a female labour force, as either family helpers or domestic cleaners. Generally speaking, all Pontios are only too well aware of the gap between their previous expectations and today's reality: 
The people who worked for twenty-five years in the Soviet Union, people like doctors and teachers have to work here as workers, as builders (Pontios association, Tiheró).

Social services again make no distinctions between the communities, although different channels are open for the EIYAPOE Agency, whose main goal is to only deal with the acquisition of houses. The result is that the Pontios seek help within their own ethnic network resources, such us in the case of health care:

We have insurance from the government. The great help for us is that many doctors in the local hospital are ours, they are Pontios. From this side we are insured, not with the law, but with our links, with our communities (Pontios association, Alexandropouli).

So far, the only possible interlocutors for the administrations have been the associations. Nevertheless, they are still in their infancy and they do not yet play an important role, with their only function being to act as meeting points. We can distinguish between two groups of Pontios associations, those of the migrants who arrived in the 1920s and the associations of the migrants of the 1990 's. Their respective aims and objectives are evidently very different, with the former aimed more at folklore and artistic activities, while the latter have to face up to pressing social problems:

For cultural and social improvement, we organise musical and dance groups for the children. With culture we can express ourselves and we can make society recognise our identity (Pontios association, Alexandropouli).

Another problem the associations have is that the origins of the recentlyarrived Pontios population is highly diverse:

We have people here from different regions: Georgia, Armenia, Russia, and Kazakhstan. Thus our association is not so solid as it should be. The divisions are regional divisions, of course we have different habits in the Caucasus than in Russia (Pontios association, Tiheró).

\section{Conclusions}

The analysis of the presence of the new and old communities in the Thracian region, brought about by the disintegration of the Ottoman Empire, is informed by the notions of diaspora and minorities, and provides us with very interesting empirical information about how to work simultaneously with commonalties and divergences in context of comparative analysis of Southern Europe. This case has shown how differences can be perceived by looking at the national level (here, Greece) through a bipartite case study, which by emphasising socio-economic differences reveals quite a lot of information about the differentiation of reception contexts where migrants arrive. In terms of com- 
monalties, we should say that in this case some characteristics of the Southern European model are perhaps exaggerated, such us the clientelistic and family-based system, the very low level of social services, and lack of alternative actors to the institutional ones in the development of social policies.

First of all, concerning the role of immigration in Southern Europe, restrictive borders and inexperienced immigration policies can be noted, whereas gender asymmetries seem to play a very different role in a rural setting (in contrast with the urbanised and tertiarised Athenian economy). In the urban setting, the genderised need for family care seems to fit much better to the new female flows; the "gender nexus» between the demand side (urban middle class family) and the supply (foreign women) is, therefore, not present. Furthermore, irregular immigration characterised by the presence of Albanians in the rest of Greece seems to be quite different in this region, where all communities we focus on have citizenship rights.

Secondly, the process of nation-state building and the definition of the foreigner leave no space for potential local social-policy dynamics. When delineating ways of accommodating minorities, two poles could be distinguished: an assimilationist and paternalistic policy of promoting the settlement of Pontios and a communitarian policy based on the Treaty of Lausanne (and on the state of the Greek-Turkish relations). Through the demography hypothesis, the homogeisation discourse and the construction of nationalism we have been able to see how the Thracian case is very difficult to solve within the Greek context, because it directly addresses the very issue of the "Greek paradox», where it recognises difference in a complex way (through a historical treaty) and promotes assimilation through a badly planned policy based (for Pontios) on short-term goals that expects urban people to settle in a rural and still economically marginalised area. The "Greek paradox" can here be discerned, on the one hand, in the way in which a hard-line assimilation strategy is pursued in order to redistribute populations and voters (complex assimilation strategies that in one way are explicitely addressed to Pontios although, implicitely, are aimed at Pomaks and Gipsies). On the other hand, there is heavy reluctance to recognise «new» cultural cleaveges, which would be perceived as a threat to a solid Hellenic equilibrium. Furthermore, the construction of each one of the identities of all these communities is still based on religion and not only on ethnicity as the was the case of the old criterion for determining who was a Turk and who was a Greek. Embedded within identity, family systems and gender relations also seem to play an important role for the construction of «new and old»communities.

The perspective used in this article based on the division of communities shows how even if those two communities are both Greek citizens their demands are certainly placed on very different levels. While Pontios associations mostly deal with cultural activities and show themselves eager to keep their old folklore, in the case of the Turkish associations their strategy is mainly political, and use a politicised discourse critical of the Greek administration and its opaque conception of diversity. In this article, through such a division, one 
could perhaps see in the long term the result of divergent policies, where Pontios will finally be assimilated into mainstream society, as their grandparents also did, and where the "Turkish-Muslim» population will try to keep fighting for the right to regulate their private life in a different way to the Greek-Orthodox community.

\section{References}

BALDWIN-EDWARDS, M. (1997). "Foreigners in Greece: the Construction of an Immigration Regime». Journal of European Social Policy and Eklogi.

Courbage, Y.; Fargues, P. (1992). Chrétiens et Juifs dans l'islam arabe et turc. Paris: Éditions Payot \& Rivages.

FAKIOLAS, R. (1994). «Migration from and to Greece». 1994 SOPEMI Report. Paris: OECD-SOPEMI.

Greek Helsinki Monitor and Minority Rights Group. Webb page. 21-1-98. http://www.greekhelsinki.gr

H.R.W. Human Rights Watch (1998). «Greece. The Turks of Western Thrace». Human Rights Watch Report, vol. 11, núm. 1(D).

KARYDIS, V. (1993). "Migrants as a Political Enterprise: The Greek-Albanian Case». Chroniques, vol. 8, p. 93-96.

NOTARAS, Gerrassimos (1995). «Les obstacles à l'intégration des musulmans de Thrace». In BISTOLFI, Robert; ZaBBAS, François. Islam's d'Europe. Intégration ou insertion communaitaire. Paris: Éditions de l'Aube.

PAPANTONIOU, A. et al. (1996). «Migrant insertion in the informal economy, deviant behaviour and the impact on receiving societies». Greek Report for the Commission of the European Community. MINGRINF Project.

Petmesidou, M. (1996). «Social Protection in Southern Europe: Trends and Prospects». Journal of Area Studies. Southern Europe in Transition. Issue 9. Autumm 1996, p. $95-125$.

PetMesidou, M.; Tsoulovis, L. (1994). «Aspects of the changing political economy of Europe: welfare state, class segmentation and planning in the postmodern era». Sociology, vol. 28, núm. 2. May, p. 99-519.

Poulton, H. (1997a). "Islam, Ethnicity and State in Contemporary Balkans». In Poulton, H.; TajI-FaOurKi, S. Muslim Identity and the Balkan State. New York: New York University Press.

- (1997b). "Changing Notions of National Identity among Muslims in Thrace and Macedonia: Turks, Pomaks and Roma». In Poulton, H.; TAjI-FaOURKI, S. Muslim Identity and the Balkan State. New York: New York University Press.

RiBAS MATEOS, N. (1997). "Greek immigration policies: the impact on immigrants and their families». Laboratorio de Estudios Interculturales. Facultad de Educación. Universidad de Granada. Septiembre 1997 (unpublished).

Taji-Faoruiki, S.; Poulton, H. (1997). «Introduction». In Poulton, H.; TajIFAOURKI, S. Muslim Identity and the Balkan State. New York: New York University Press.

VERNIER, Bernard (1981). «Représentation mythique du monde et domination masculine chez les Pomakes Grecs». The Greek Review of Social Research. Numéro Spécial. Aspects du changement social dans la campagne grecque. EKKE, p. 121-142. 